\title{
An Assessment on the Economic Benefit of Cactus Crop in the Case of Ganta Afeshum District, Eastern Tigray, Ethiopia
}

\author{
Fikre Belay \\ Department of Geography and Environmental Studies, College of Social Science and Humanities, Adigrat University, Adigrat, Ethiopia \\ Email address: \\ fikrebelay23@yahoo.com \\ To cite this article: \\ Fikre Belay. An Assessment on the Economic Benefit of Cactus Crop in the Case of Ganta Afeshum District, Eastern Tigray, Ethiopia. \\ American Journal of Environmental Protection. Vol. 4, No. 5, 2015, pp. 202-206. doi: 10.11648/j.ajep.20150405.11
}

\begin{abstract}
Cactus is a plant with very thick and fleshy stems. It is often covered with prickles and it usually grows in desert and semi desert area of the world. Cactus has different benefit such as source of food, medicine, chemical and income. Therefore, the objective of this research was carried out to assess the economic benefit of cactus as potential source of food for both human and animal in Ganta Afeshum District, Eastern Tigray region of Ethiopia. For this study, questionnaires, structured interviews, field observations and documentary analysis were applied to collect the necessary information from farm households and concerned bodies. Probability and non - probability sampling methods were used in this study. The sample is selected using simple random sampling from the entire target of population (1230, which is $135(11 \%)$. Both quantitative and qualitative methods of data analysis were used to describe the findings. Tables, charts and percentage were used in summarizing the quantitative data. The survey result shows that in the study area out of the total area of the District, 1607.05 hectare of the land is covered by cactus crop. Even though the area is characterized by a potential on cactus crop but the farmers used cactus crop only as diet for human being and as forage for animals particularly for cattle.
\end{abstract}

Keywords: Cactus, Economic, Social, Benefit

\section{Introduction}

Ethiopia is one of the most well endowed countries in terms of natural resources including fauna and flora (Gete et al., 2006). However, the country faces different problems like soil erosion (Million and Kassa, 2004). The cause for this is manly associated with land cover change (Woldeamlak, 2002).

Cactus is a plant with very thick and fleshy stems. It is often covered with prickles and it grows in desert and semi desert area of the world which is high tolerant to drought (Barbera, 1995). Cactus crop contains water (92\%), carbohydrates $(4-6 \%)$, protein $(12 \%)$, minerals $(1 \%)$, and moderate amount of vitamins mainly $\mathrm{A}$ and $\mathrm{C}$ (Cantwell, 1991).

Typical values for nutritional components in these studies were found to be: moisture content, $85-90 \%$; crude protein, 5-12\%; phosphorus, $0.08-0.18 \%$; calcium, $4.2 \%$; potassium, $2.3 \%$; magnesium, $1.4 \%$; energy, $2.6 \mathrm{Mcal} / \mathrm{kg}$. The in vitro digestibility values were $72 \%$ for protein, $62 \%$ for dry matter, $43 \%$ for crude fiber and $67 \%$ for organic matter (Cantwell,
1991).

Clodadose (cactus leaf) is very important to prepare salad, ice cream and juice. Clodadose (cactus leaf) is used for marmalade and cactus fruit also used for marmalade and candy (Mums for Mums, 2004). Cactus serves as raw material for cosmetic products like shampoo, soap, cream and body lotion. Adhesive and glues, pectins, fibers for hand crafts and papers can be made from cactus; the vegetative material is used with bovine manure as an anaerobic digestion accelerator to produce biogas (Uribe et al, 1992).

According to popular medicine cactus especially its cladode is remedy for diabet mellitus, diarrhea (Corrales-Gracia et al, 2004).

Cactus introduced via Erob District in the $19^{\text {th }}$ century by catholic missionary called Bishop AbuneYackob planted in Erob (Frew, 2007). Today cactus is grown in Eastern Tigray in Erob, Saesie TsadaEmba, and Ganta-Afeshum District. Out of the total area of Ganta-Afeshum District (53035.30 hectare), 1607.05 hectare covered by cactus crop (Ganta Afeshum District administration yearbook, 2012 and Ganta Afeshum Rural and Agricultural office report, 2012). 
More over cactus has different economic benefits. Despite the more than 1607.05 hectare is covered with cactus crop in Ganta-Afeshum District, however the farmers have little or no knowledge concerning the different economic benefits of cactus crop, therefore the researcher inspired to explore the different economic benefit of cactus and to recommend possible solution.

Objective of the study

The main objective of this study is to assess the economic benefit of cactus as potential source of food for both human and animal and to create an awareness on feeding of cactus crop (as salad, juice and marmalade and bread etc).

\section{Site Description (Location)}

One of the 36 woredas in the Tigray Region of Ethiopia and part of the Misraqawi Zone, Ganta Afeshum is bordered on the south by Hawzen, on the west by the Mehakelegnaw (Central) Zone, on the north by Gulomahda, and on the east by Saesi Tsaedaemba. Towns in Ganta Afeshum include Adigrat and Bizet. The 1994 national census reported a total population for this woreda of 122,827 of whom 58,398 were men and 64,429 were women; 39,561 or $32.21 \%$ of its population were urban dwellers. The largest ethnic group reported in Ganta Afeshum was the Tigrayan $(98.07 \%)$. The total area of this District is $530.35 \mathrm{~km}^{2}$ and with total population 53,339.(Ganta Afeshum District Administration 2012).
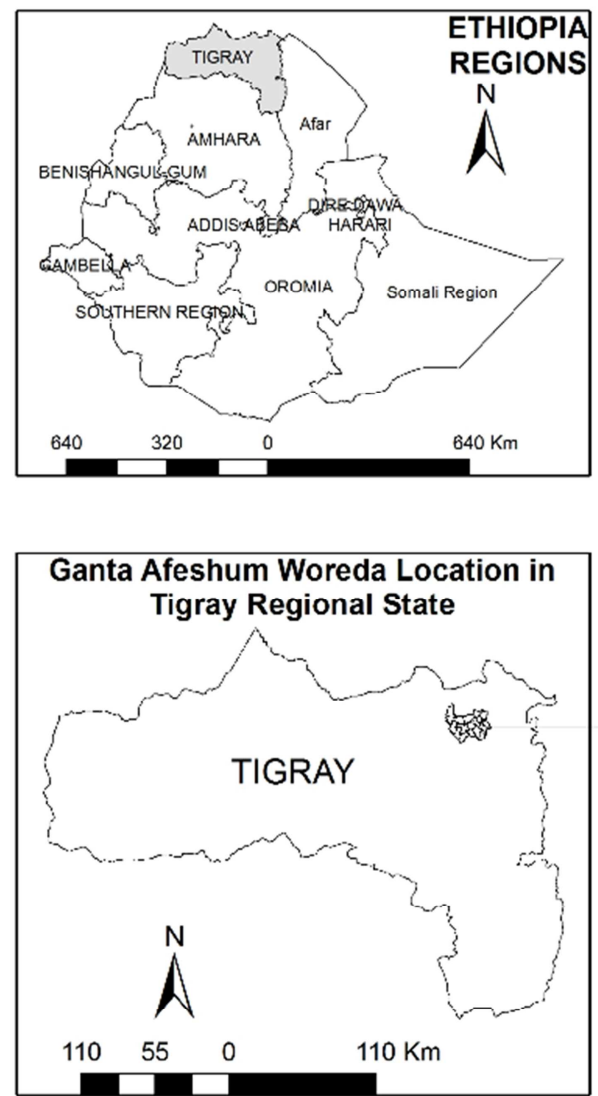

\section{Methodology}

\subsection{Sampling Techniques and Designs}

The study was conducted in Ganta Afeshum District, Eastern Tigray Zone of Tigray State in 2014. The District was selected due to the fact that there was more Cactus is growing in the area. For this study descriptive type of research was employed to describe the characteristics of variables in the study area.

Probability and non- probability sampling were used in this study. Probability especially systematic sampling was used for households. The households were selected using simple random sampling technique from the entire target of

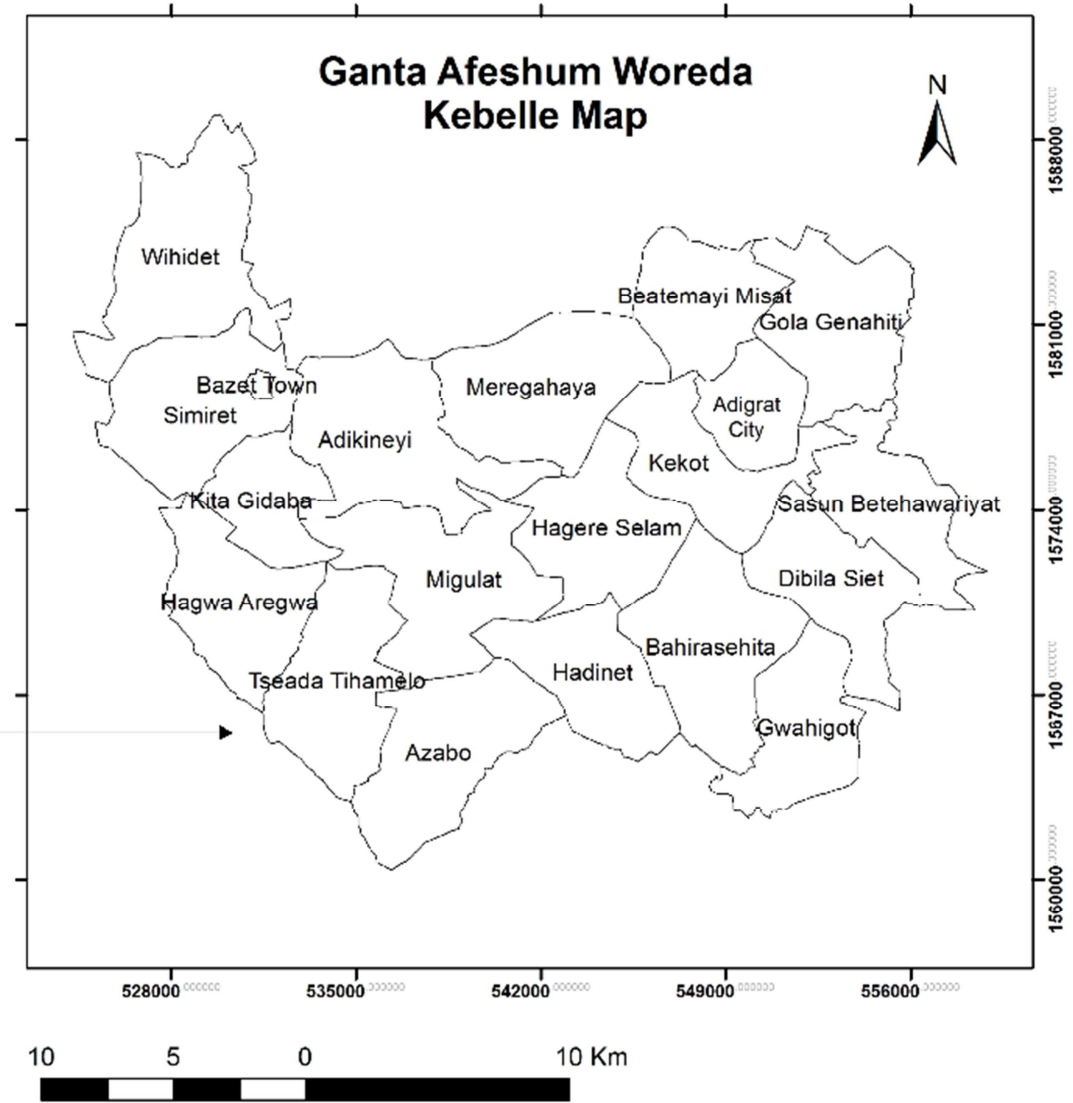

Figure 1. Location map of the study area.

population (1230, which is $135(11 \%)$

\subsection{Methods of Data Collection}

Both primary and secondary sources of data were used in this study. Secondary sources of data were obtained from various published and unpublished sources of the governmental and non-governmental organizations. Internet sources and research reports were employed for acquiring the necessary information. Primary data were obtained through schedule household questionnaire (structured questionnaires with close-ended and open-ended), Interview (unstructured) and observation. 


\section{Results and Discussion}

\subsection{Cactus Crop Classification in the Study Area}

From the above table we can understand that (Table 1) $6.66 \%$ of the household answer concerning their house condition that the color of Cactus is white, $80 \%$ replied that the color of Cactus is green and $13 \%$ of the respondents replayed that the color of Cactus is red.

Table 1. Types of cactus in Ganta Afeshum.

\begin{tabular}{llll}
\hline \multirow{2}{*}{ Characteristics } & Item & \multicolumn{2}{l}{ Respondents } \\
\cline { 2 - 4 } & No & Percentage \\
\hline \multirow{3}{*}{ Color type } & A. White & 9 & 6.66 \\
& B. Green & 108 & 80 \\
& C. Red & 18 & 13 \\
& D. No response & 0 & 0 \\
& Total & 135 & 100 \\
The type of cactus grown & A. Planted by man & 14 & 10 \\
in the study area & B. Naturally grown & 1 & 0.7 \\
& C. Both & 120 & 86.9 \\
& D. No response & 0 & 0 \\
The type of cactus in & Total & 135 & 100 \\
terms of spine & A. With spine & 100 & 72.5 \\
& B Without spine & 15 & 10.8 \\
& C. Both & 20 & 14.5 \\
\hline
\end{tabular}

Source: Field data May 2014

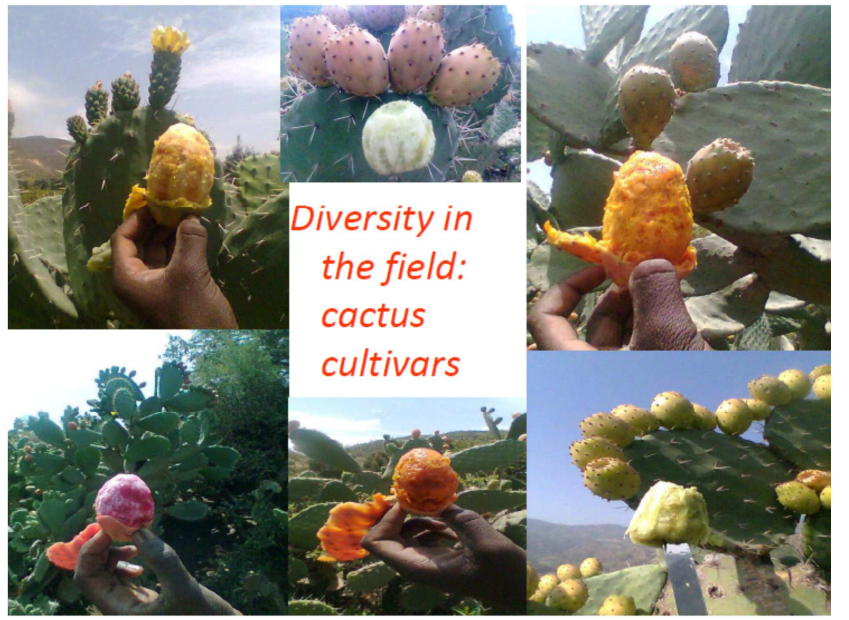

Figure 2. Types of cactus.

On the other hand concerning the type of cactus grown in the study area, $10 \%$ of the households replied that in the area Cactus is grown or planted by man, $0.7 \%$ of respondents replayed that Cactus is grown naturally and $86.9 \%$ of the respondents replayed that Cactus is grown by man and in naturally. On the other hand, the household's response concerning the spine type, $72.5 \%$ replied that cactus with spine in their locality whereas $10.8 \%$ answered without spine and $14.5 \%$ replied that both.

\subsection{Use of Cactus Plant}

Identification of medicinal plants with their characteristics is important for botanical drug industry (Esra et al. 2015,
Francisco et al. 2015). Different parts of cactus as a potential source of food for both human and animals. From table 2 we can understand that different parts of cactus like Leaf, Fruit and Cladodes is important for preparing forage, Juice and medicine.

As can be seen in Table 2, among the different parts of Cactus the majority of the respondents $(70.4 \%)$ they used cactus fruit as a source of diet and $2.96 \%$ of the House Holds replied that cactus leaf use as diet. On the other hand the majority of the households $(66.66 \%)$ used Cactus Cladodes for preparing and uses as forage and $22.2 \%$ of the households replayed that Cactus fruit is used as forage.

Table 2. The benefit of cactus as diet, forage or chemical in Ganta Afeshum.

\begin{tabular}{|c|c|c|c|}
\hline \multirow{2}{*}{ Characteristics } & \multirow{2}{*}{ Item } & \multicolumn{2}{|c|}{ Respondents } \\
\hline & & No & Percentage \\
\hline \multirow{5}{*}{$\begin{array}{l}\text { Different part of } \\
\text { cactus uses as diet }\end{array}$} & A. Leaf of Cactus & 4 & 2.96 \\
\hline & B. Fruit & 95 & 70.4 \\
\hline & C. Both & 20 & 14.8 \\
\hline & D. No response & 6 & 4.44 \\
\hline & Total & 135 & 100 \\
\hline \multirow{5}{*}{$\begin{array}{l}\text { Different part of } \\
\text { cactus uses as } \\
\text { forage }\end{array}$} & A. Cladodes & 90 & 66.66 \\
\hline & B. Fruit & 30 & 22.2 \\
\hline & C. Both & 15 & 11.11 \\
\hline & D. No response & 0 & 0 \\
\hline & Total & 135 & 100 \\
\hline \multirow{6}{*}{$\begin{array}{l}\text { Different part of } \\
\text { cactus uses for } \\
\text { different purpose }\end{array}$} & A. For Medicine & 4 & 2.96 \\
\hline & B For juice or $T e j$ & 3 & 2.22 \\
\hline & C. For marmalades \& salads & 6 & 4.44 \\
\hline & D. No advantage for all & 120 & 88.88 \\
\hline & E. No response & 2 & 1.48 \\
\hline & Total & & 100 \\
\hline
\end{tabular}

Source: Field data May 2014
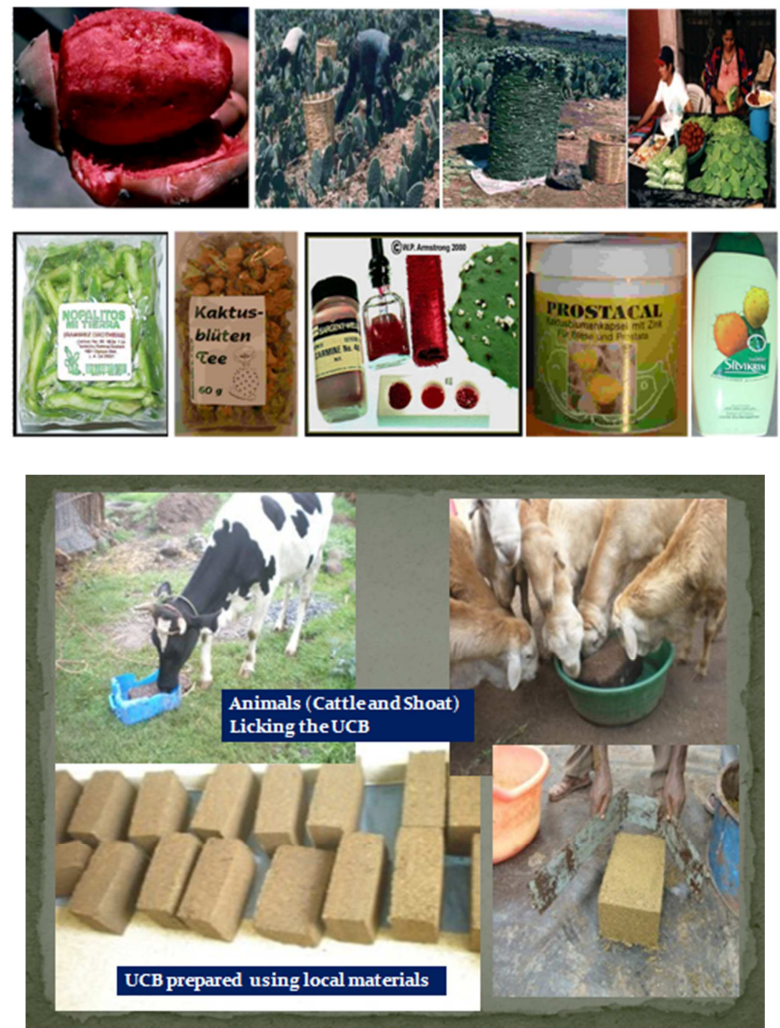

Figure 3. Important of cactus for different purpose. 
Table 3. The benefit of cactus in addition as diet, forage or chemical in Ganta Afeshum.

\begin{tabular}{|c|c|c|c|}
\hline \multirow{2}{*}{ Characteristics } & \multirow{2}{*}{ Item } & \multicolumn{2}{|c|}{ Respondents } \\
\hline & & No & Percentage \\
\hline \multirow{6}{*}{$\begin{array}{l}\text { The benefit of cactus in addition as diet, forage or } \\
\text { chemical }\end{array}$} & A. for fertilizer & 2 & 1.48 \\
\hline & B. for soil conservation & 50 & 70.4 \\
\hline & C. For fence & 80 & 14.8 \\
\hline & D. For timber & 3 & 2.22 \\
\hline & D. No response & 0 & 0 \\
\hline & Total & 135 & 100 \\
\hline
\end{tabular}

Source: Field survey May 2014

Even though different parts of Cactus is used for preparing juice and medicine, but the households didn't use cactus as a source of juice and medicine. Only $2.96 \%$ of the households replied that cactus crop used as preparing medicine and $22 \%$ of households replied that cactus crop used for preparing juice or Tej (local drink).
Cactus has a variety of benefits for the community of study District. As depicted in the above table, more than $70 \%$ of the households in the area explained as cactus is important for soil conservation by holding of soils run by erosion. More than $14 \%$ of the households replied that cactus is very useful for fence. It is also purposeful for timber production and for fertilizer.

Table 4. The benefit of cactus as source of income, improving living standard of the households in Ganta Afeshum.

\begin{tabular}{|c|c|c|c|}
\hline \multirow{2}{*}{ Use of cactus } & \multirow{2}{*}{ Item } & \multicolumn{2}{|c|}{ Respondents } \\
\hline & & No & Percentage \\
\hline \multirow{5}{*}{ Commercial value } & A. Leaf of Cactus & 4 & 2.96 \\
\hline & B. Fruit & 101 & 74.8 \\
\hline & C. Both & 20 & 14.8 \\
\hline & D. No response & 0 & 0 \\
\hline & Total & 135 & 100 \\
\hline \multirow{5}{*}{$\begin{array}{l}\text { Amount income from cactus fruit per kintal ( } 1 \text { kilo contains } \\
\text { average } 05-07 \text { pieces of fruits) in terms of Birr }\end{array}$} & A. $300-500$ & 90 & 66.66 \\
\hline & B. $600-1000$ & 30 & 22.2 \\
\hline & C. $>1000$ & 15 & 11.11 \\
\hline & D. No response & 0 & 0 \\
\hline & Total & 130 & 100 \\
\hline \multirow{5}{*}{ improving living standard of the households } & A. High & 13 & 9.62 \\
\hline & B Medium & 70 & 51.8 \\
\hline & C. Low & 50 & 37 \\
\hline & D. No response & 2 & 1.48 \\
\hline & Total & 135 & 100 \\
\hline
\end{tabular}

Source: Field data May 2014

As per the above table, more than $74 \%$ of the respondents replied that fruit of cactus has commercial value. Regarding that cactus having income value, $66 \%$ of farmers are sure that they gain on average 300 to 500 birr per annum from cactus sales. Hence, it improved living standard of low income households.

\section{Conclusion}

As obviously known, cactus has different economic benefits and source income in different part of the world but the household should not consider as source income this is duet-to the limited knowledge of the farmers concerning the economic benefit of cactus. In the study area 167.05 hectare of the area was covered by cactus but the housel's conceder its fruit as additional diet for human being and as forage for animals. This is due to the educational level of the society is low and they give less attention to cactus crop than other crops. Therefore, concerned bodies should give awareness and training to the community regarding to the benefits of cactus and establishing cactus association to facilitates the cactus production and provide fertile ground to the farmers to supply cactus for market in order to increase their income.

\section{References}

[1] Barbera, G. 1995. History, economic and agro-ecological importance. In: Barbera, G. Inglese, P., Pemineta - Barrior, E. (Eds), Agro-ecology, cultivation and uses of cactus pear, vol.132. FAO Plant Production and Protection Paper, pp. 1-11.

[2] Cantwell, M. 1991. Quality and postharvest physiology of "nopalitos" and "tunas". Proc. $2^{\text {nd }}$ Annual Texas Prickly Pear Conference, Texas Prickly Pear Council, McAllen, Texas. Pp.50-60.

[3] Corrales-Grcia, Jpenavaldvia, CB; Razo Martinez, Y, Sanchez-Hermandaez, M. 2004. Acidity changes and pH-buffering capacity of napalitos (opuntia ssp.).Post harvest Biol.Tech. 32,169-174.

[4] Esra Maltas, Aslı Dageri, Hasibe Cingilli Vural, Salih Yildiz, Investigation on Biochemical and Molecular Analysis of Echinacea Genotypes, Plant. Vol. 3, No. 1, 2015, pp. 1-7. doi:10.11648/j.plant.20150301.11. 
[5] Francisco das Chagas Dourado de Sousa, Melise Pessôa Araújo, Jesus Rodrigues Lemos, Ethnobotanical Study with Native Species in a Rural Village in Piauí State, Northeast Brazil, Journal of Plant Sciences. Vol. 3, No. 2, 2015, pp. 45-53. doi: 10.11648/j.jps.20150302.11.

[6] Frew Tegegn. 2007. Evolution of alternative feed resources for ruminants under arid zone of the tropics and sub tropics: the case of cactus pears in Ethiopia, Humboldt University, Berlin. Tag der Wissenschaftlichen Aussprache. ISBN 978-3-89574-634-5.

[7] Gete Zeleke, Menale Kassie, Pender, J. and Mahmud Yesuf. 2006. Stakeholder Analysis for Sustainable Land Management (SLM) in Ethiopia: Assessment of Opportunities, Strategic Constraints, Information Needs, and Knowledge Gaps. Environmental Economics Policy Forum for Ethiopia (EEPFE). Ethiopia.
[8] Million Tadesse and Kassa Belay. 2004. Factors Influencing Adoption of Soil Conservation Measures in Southern Ethiopia: The Case of Gununo Area. Journal of Agriculture and Rural Development in the Tropics and Subtropics. Vol. 105(1): 49-62.

[9] Mums for Mums. 2004. Preparation of cactus (Beles) recipes, Mekelle Institute of Technology, Mekelle.

[10] Uribe, J.M., Varnero, M., I, Benavides, C., 1992. Biomas of prickly pear (Opuntia ficus-indica L. Mill) as bovine manure anaerobic digestion accelerator.Simiente.62, 14-18 (Abstract).

[11] Woldeamlak Bewket. 2002. Land Cover Dynamics since the 1950s in Chemoga Watershed, Blue Nile Basin, Ethiopia. Mountain Research and Development. Vol. 22 (3): 263-269. 